\title{
Reliability of Software Correlated Components Failure in Pakistan Industry
}

\author{
Darakshan Anjum \\ University of Agriculture/ Computer Science, Faisalabad, 38000, Pakistan \\ Email: darakshan.anjum87@gmail.com \\ Tasleem Mustafa \\ University of Agriculture/ Computer Science, Faisalabad, 38000, Pakistan \\ Email: tasleemustafa@uaf.edu.pk
}

\begin{abstract}
Now-a-days most important issue of software engineering in Pakistan industry is the correlated component failure, such failure occur when on component of the software is fail to work according to the specification and other related module to the specific component is also fail to perform the work. Due to this reason whole system destruction is possible as well as software development time and cost may be increased. The purpose of the study is to analyze the probability of software correlated component failure before the implementation and also analyze the main factor that cause of software correlated failure in Pakistan industry. Data is collected from software houses by using the data gathering techniques such as survey and interviews.

After doing statistical analysis by using bar chart conclude that in Pakistan industry main reason of software failure is error in software resource analysis in addition to faults in testing of the software. To overcome these issues in future it's important to improve the testing phase of the software development process and during development of the software better techniques used for the resource allocation process.
\end{abstract}

Index Terms-Correlated Failure, software reliability Software testing, Error in software development phase, requirement gathering.

\section{INTRODUCTION}

With the passage of time size and complexity of software is increasing in past many decades. Due to the complexity of the software it is required to analyze to which extend software is reliable before implementation. There is inverse relationship between software reliability and fault or failure. If the numbers of faults increase then the software quality decreases. So estimate the quality of the software, it needs to check how much software is reliable (Jatain and Yukti, 2014).

Software is key feature of number of devices which are used in the world so for this perspective it's important to estimate the quality of the software, and it also assure that high quality software is produced if software testing is perform in better manner. As the software quality perspective testing of the product play an important role, it analysis that quality of the software is different for different product and customer perspective. Discuss the different quality aspects are bellow (Ammann and Offutt, 2011).

There are number of reasons for the failure of software but the most common is the correlated component failure, observations concluded that single module failure causes the failure of other multiple module related to the previous module of the software. This type of related fault and failure are due to number of reasons such as requirements fault, coding fault, and data gathering problems (Hamill and Goseva-Popstojnova, 2009).

Our descendants not pay attention on the correlated component failure of the software because at that time software were not complex enough. Now-a-days as the software complexity is increase, correlated component failure creates problems, when the fault or failure is detected at the later stages or after the implementation phase then the development time and cost will increase. To overcome this problem, analyze the probability of correlated component failure. By studying the number of case studies, it is concluded that component failure is statistically co-related (Fiondella and Panlop, 2014).

Estimating the correlated component reliability is a useful technique but sometimes it may be difficult to analyze the probability of component failure. Different reliability growth models are used to estimate the software correlated component reliability. Through analyzing the reliability of correlated component achieving a failure-free and reliable software (Ikemotoet al., 2013).In embedded system, software play an important role for the hardware so the failure of software cause the failure of hardware that's why in embedded systems correlated component failure cause the failure of the whole system. However many researchers concluded that mostly software failure is due to the co-related component failure (Park et al.,2012).

Software is also very important in different fields such as e-commerce, medical devices, industrial and mobile applications in which the failure of software component may cause the serious financial losses, death or the claps of whole application. so required to develop a system which is reliable while different components are integrated(Broschet al.,2012). 
Successful execution of correlated component depends on the type of operation which are perform and also based on the extent that how much internal state of the software is effected (Dai at el., 2005). The purpose of the study is to enhance the knowledge about the software correlated component failure in Pakistan industry and purpose a method through which estimate the related component reliability before the implementation phase.

\section{Problem StATEMENT}

Software engineering is an important branch of computer field, main focusing on the development of the software. In this research the factors which are the cause of the software failure and also the issue of software correlated component failure in Pakistan are discussed. These areas were major software engineering challenges in moving further in software based applications development.

\section{RELATED WORKS}

Jafary and Fiondella (2016) stated the multi state system (MSS) reliability modeling which estimate the reliability of both system and components, in past many decades most of the researcher claims that correlation of MSS provide bad effect on the system performance while the software is more complex. He explained a discrete universal generating function method to correlate the elements of the software with multi state components. This approach is in the diagnostic form and provides efficient performance, reliability assessment as well as sensitivity analysis on the impact of correlation. He clarified that through this strategy assess the effect of correlation on software performance, reliability and efficiency.

Nagaraju et al. (2016) stated that now-a-days social order more and more focus on the software based a service that's why it becomes important that give more importance to the reliability and availability of the software to minimize the affect of software failure rejuvenation technique is used. This method also helps to reduce the affect of individual failure on software or system availability. He explained that though this method server availability is increased as well as cost is decrease. Proposed method is efficient and reliable and gives optimal rejuvenation period.

Febrero et al. (2016) stated that due to the widely use of the software based system now it necessary to give more alert on developing the error free software. For this purpose main focus of the developer is to develop reliable software and estimate the probability of software correlated component failure. He explained a literature research for anal sizing the importance of software reliability. He used a Standard Based Software Reliability Modeling (SB-SRM) technique to estimate the software correlated component failure. Through this qualitative method conclude that the proposed technique is also applied on complex organizations. Through this survey study also psychoanalysis that correlated component failure is main issue while dealing the software reliability. Proposed technique is efficient and reliable method to measure the importance of software reliability in any organization.

Garousi and Mantyla (2016) stated that for decrement of test code many organizations used test automation technique. through this method try to estimate the correlated software component failure by anal sizing the minimum software code, the proposed technique is also helps us to reduce the software development as well as software testing time. He explained that the given approach provide fruitful output only when it used in correct time, and context. Decision about the application of this technique is most important, because the success of the software project main focus on the software testing and estimating the software correlated component failure before implementation phase. He stated that for the implementation of this approach used Multifocal Literature Review (MLR) study through this method measure that what and when to automate the software testing. It concluded the test automation is a cheaper and easiest way to check the software reliability as well as software correlated component failure.

Saito and Dohi (2016) stated that non-parametric software reliability analysis is a huge issue. it is difficult to estimate the software reliability when there is incomplete information about software faults and failure at the development phase. The stochastic models just only provide information about software failure and faults it not give enough knowledge about unknown parameter of the model and software. The Monotone nonparametric estimator just provides information about the fulty data not about the time to failure and it also very rare to provide in practice. Now to revise this approach to test the software reliability and try to develop both estimation and predict quality of the software reliability. He experiment on thirteen project data and compare it with the previous parametric models and concluded that non-homogenous Poisson Process-based software reliability models is more efficient unique and east way to estimate the probability of software correlated component failure as well as estimation of the software reliability.

Yang et al (2016) stated that in complex and large software system software houses perform a regular upgrading so by this process faults and failure of the past rendition of the product is evacuate and the new functionalities add into the software. However when software introduced in the market it suppose that it is error free and high quality as per the customer requirement. He explained the testing in multi-release software and estimates that when there is delay in fault repair time then it means that there should be delay in software model. The proposed model is applied when software is released third time into the market. So this process of software reliability estimation is more cost effective and easy to apply in different software models. This technique is also helpful to provide software or product in time to the customer. 


\section{MATERIALS AND METHODS}

Research methodology forms the basic idea on which the research is conducted. Conducting research and collecting data depends solely on research methodology. It can be defined as a method or technique of solving the problems systematically and scientifically. Moreover the purpose of research methodology is not only to describe the techniques and processes involved in data collection but also to understand the logic behind the methods that have been chosen for the purpose of any particular research (Kothari, 2006).

Two major types of research approaches used in primary are inductive and deductive approaches. The processes involved the inductive approaches.

In this research, simple random sampling based technique was used and a set of 83 companies from major locations of Pakistan were selected in such a way that the population represents overall software industry in Pakistan. For this purpose questionnaire was sent to 200 companies from Lahore, Karachi and Islamabad out of which only 83 valid responses were selected for data analysis.

\section{RESULTS AND DISCUSSION}

Software is used in every field of life especially realtime software in medical and army fields, in this perspective it become important to analyze the each and every aspect of the software, there are number of reasons that cause the software failure and the most common one is the software correlated component failure. In this aspect it's important to analyze the factor that causes the software failure before introducing the software to the market. After doing various studies it examine that software failure are related to each other (Fiondella and Rajasekaran, 2013).It analyze that software component are correlated to each other on the bases of the design phase. This means in design phase it defines that which component output base on the other component input. Such kinds of dependability are the reason of the software failure (Zhai et al., 2016).Different Factor that affects the reliability of the software in

Pakistan industry or the causes of the correlated component failure is discussed in this search. As we know that Pakistan is a developing country so there are so many issues in every field of life such as, resources, educated operators and etc, so in the same way Pakistan software development industry faces some major issues, while developing the software. Some important issues which faced by the industry are discussed bellow.

- Badly define software security policy while developing the software

- Resource allocation during the software development process

- Complexity of the software

- Software design faults

- Badly perform the requirement gathering process
- Untrained or Uneducated Software Developer

- Untrained or Uneducated Software Operator

- Problems of software testing phase

- Software developing environment

- Software operating environment

- Late identification of the faults

- Complexity of the software

- Software design faults

These issues are discussed in the proposed research and analyze that which factor are the main reason of the software correlated failure in Pakistan industry.

\section{A. Software Reliability Analysis}

Table 1. Frequency of Software Reliability Analysis

\begin{tabular}{|l|r|r|r|r|}
\hline & Frequency & Percent & $\begin{array}{c}\text { Valid } \\
\text { Percent }\end{array}$ & $\begin{array}{c}\text { Cumulative } \\
\text { Percent }\end{array}$ \\
\hline Agree & 41 & 49.4 & 49.4 & 49.4 \\
Disagree & 7 & 8.4 & 8.4 & 57.8 \\
Strongly & 30 & 36.1 & 36.1 & 94.0 \\
Agree & & & & \\
Strongly & 3 & 3.6 & 3.6 & 97.6 \\
Disagree & 2 & 2.4 & 2.4 & 100.0 \\
Neutral & 83 & 100.0 & 100.0 & \\
Total & & &
\end{tabular}

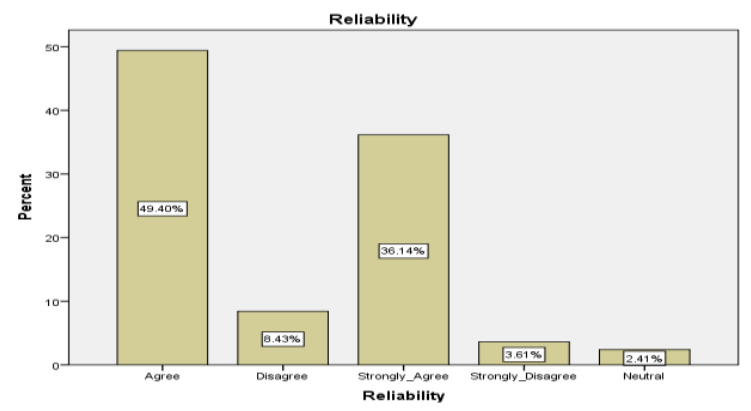

Fig.1. Software Reliability Analyses

\section{Interpretation}

To analyze that at which extent reliability estimation is important for the software, after doing a survey almost $85 \%$ companies documented the importance of reliability estimation before the product introduced to the market.

\section{B. Correlated Failure Analysis}

Table 2 Frequency of Correlated Failures Analysis

\begin{tabular}{|l|r|r|r|r|}
\hline & Frequency & Percent & $\begin{array}{c}\text { Valid } \\
\text { Percent }\end{array}$ & $\begin{array}{c}\text { Cumulative } \\
\text { Percent }\end{array}$ \\
\hline Agree & 43 & 51.8 & 51.8 & 51.8 \\
Disagree & 8 & 9.6 & 9.6 & 61.4 \\
Strongly & 27 & 32.5 & 32.5 & 94.0 \\
Agree & & & & \\
Strongly & 2 & 2.4 & 2.4 & 96.4 \\
Disagree & 3 & 3.6 & 3.6 & 100.0 \\
Neutral & 83 & 100.0 & 100.0 & \\
Total & & & & \\
\hline
\end{tabular}




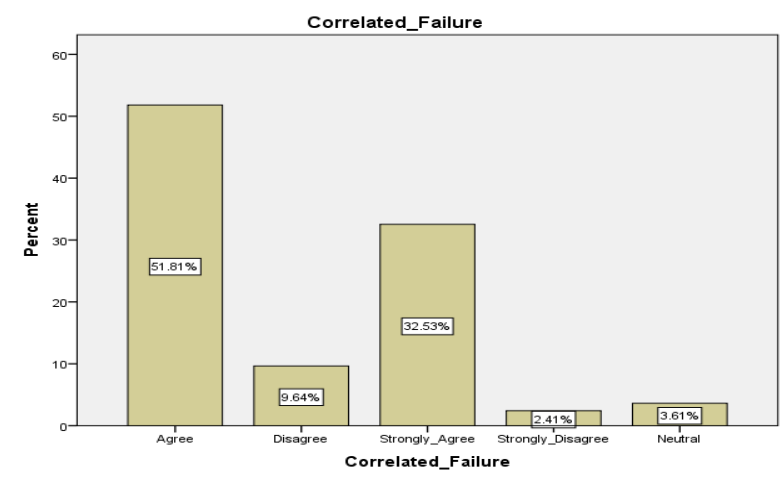

Fig.2. Correlated Failures Analysis

\section{Interpretation}

To analyze that at which extent correlated component failure are the cause of the software breakdown, after doing a survey almost $83 \%$ companies recognized that software disaster are due to the correlated failure of the software.

\section{Software Complexity Analysis}

Table 3. Frequency of Software complexity Analysis

\begin{tabular}{|c|c|c|c|c|}
\hline & Frequency & Percent & $\begin{array}{c}\text { Valid } \\
\text { Percent }\end{array}$ & $\begin{array}{c}\text { Cumulative } \\
\text { Percent }\end{array}$ \\
\hline Agree & 36 & 43.4 & 43.4 & 43.4 \\
\hline Disagree & 6 & 7.2 & 7.2 & 50.6 \\
\hline $\begin{array}{l}\text { Strongly } \\
\text { Agree }\end{array}$ & 20 & 24.1 & 24.1 & 74.7 \\
\hline $\begin{array}{l}\text { Strongly } \\
\text { Disagree }\end{array}$ & 3 & 3.6 & 3.6 & 78.3 \\
\hline Neutral & 18 & 21.7 & 21.7 & 100.0 \\
\hline Total & 83 & 100.0 & 100.0 & \\
\hline
\end{tabular}

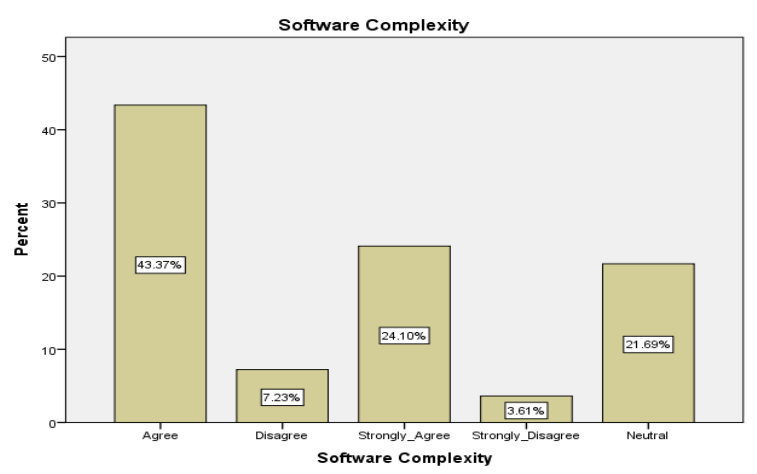

Fig.3. Software Complexity Analysis

\section{Interpretation}

To analyze that at which extent software correlated component failure occur due to the complexity of the software, after doing a survey almost $67 \%$ companies recognized that cause of correlated failure is complexity.

\section{Requirement Elicitation Analysis}

Table 4. Frequency of Requirement Elicitation

\begin{tabular}{|l|r|r|r|r|}
\hline & Frequency & Percent & $\begin{array}{c}\text { Valid } \\
\text { Percent }\end{array}$ & $\begin{array}{c}\text { Cumulative } \\
\text { Percent }\end{array}$ \\
\hline Agree & 27 & 32.5 & 32.5 & 32.5 \\
Disagre & 6 & 7.2 & 7.2 & 39.8 \\
e & & & & \\
Strongl & 35 & 42.2 & 42.2 & 81.9 \\
y Agree & & & & \\
Strongly & 3 & 3.6 & 3.6 & 85.5 \\
Disagree & 12 & 14.5 & 14.5 & 100.0 \\
Neutral & 83 & 100.0 & 100.0 & \\
Total & & & \\
\hline
\end{tabular}

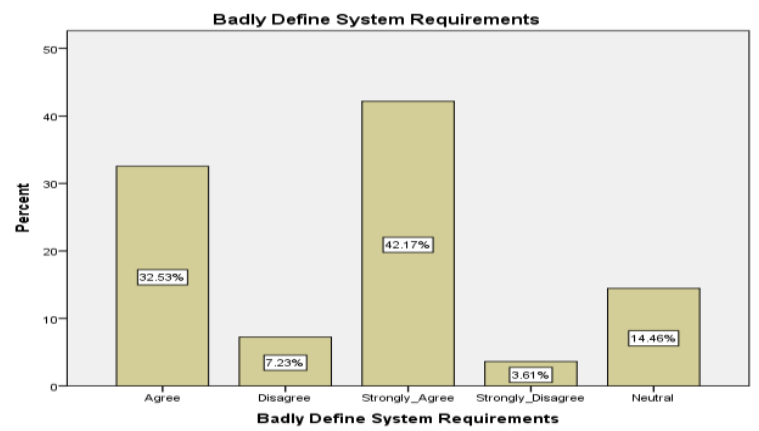

Fig.4. Requirement Elicitation Analyses

\section{Interpretation}

To analyze that at which extent software correlated component failure occur due to the bad requirement elicitation process, after doing a survey almost $74 \%$ companies recognized that cause of correlated failure is that requirement gathering is not perform in an efficient manner.

\section{E. Software Operator Analysis}

Table 5. Frequency of Software Operator Analysis

\begin{tabular}{|l|l|l|l|l|}
\hline & Frequency & Percent & $\begin{array}{l}\text { Valid } \\
\text { Percent }\end{array}$ & $\begin{array}{l}\text { Cumulativ } \\
\text { e Percent }\end{array}$ \\
\hline $\begin{array}{l}\text { Agree } \\
\text { Disagree }\end{array}$ & 34 & 41.0 & 41.0 & 41.0 \\
Strongly Agree & 14 & 9.6 & 9.6 & 50.6 \\
Strongly & 16.9 & 16.9 & 67.5 \\
Disagree & 5 & 6.0 & 6.0 & 73.5 \\
Neutral & 22 & 26.5 & 26.5 & 100.0 \\
Total & 83 & 100.0 & 100.0 & \\
\hline
\end{tabular}




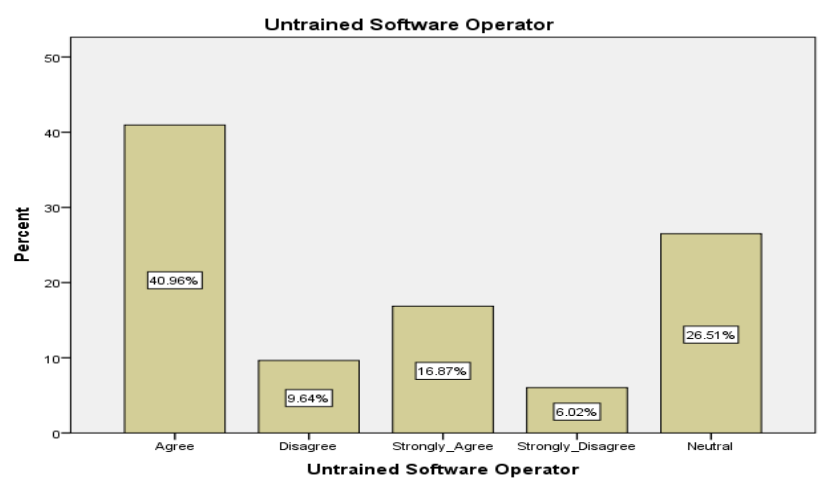

Fig.5. Software Operator Analyses

\section{Interpretation}

To analyze that at which extent software correlated component failure occur due to the untrained software operator, after doing a survey almost $57 \%$ companies recognized that cause of correlated failure is untrained software operator.

\section{F. Software Resource allocation Analysis}

Table 6. Frequency of Software Resource Analysis

\begin{tabular}{|c|r|r|r|r|}
\hline & Frequency & Percent & $\begin{array}{c}\text { Valid } \\
\text { Percent }\end{array}$ & $\begin{array}{c}\text { Cumulative } \\
\text { Percent }\end{array}$ \\
\hline Agree & 33 & 39.8 & 39.8 & 39.8 \\
Disagree & 4 & 4.8 & 4.8 & 44.6 \\
Strongly & 37 & 44.6 & 44.6 & 89.2 \\
Agree & & & & \\
Strongly & 2 & 2.4 & 2.4 & 91.6 \\
Disagree & 7 & 8.4 & 8.4 & 100.0 \\
Neutral & 83 & 100.0 & 100.0 & \\
Total & & &
\end{tabular}

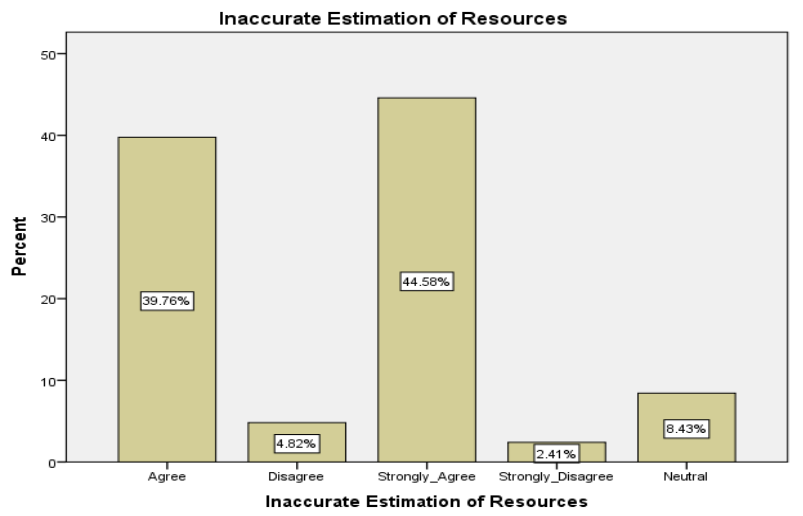

Fig.6. Software Resource Analyses

\section{Interpretation}

To analyze that at which extent software correlated component failure occur due to the inaccurate estimation of needed resources, after doing a survey it conclude that almost $83 \%$ companies recognized that cause of correlated failure is wrong analysis of resources.

\section{G. Software Technology Analysis}

Table 7. Frequency of Software Technology Analysis

\begin{tabular}{|l|r|r|r|r|}
\hline & Frequency & Percent & $\begin{array}{c}\text { Valid } \\
\text { Percent }\end{array}$ & $\begin{array}{c}\text { Cumulativ } \\
\text { e Percent }\end{array}$ \\
\hline Agree & 42 & 50.6 & 50.6 & 50.6 \\
Disagree & 5 & 6.0 & 6.0 & 56.6 \\
$\begin{array}{l}\text { Strongly } \\
\text { Agree }\end{array}$ & 14 & 16.9 & 16.9 & 73.5 \\
Strongly & 5 & 6.0 & 6.0 & 79.5 \\
$\begin{array}{l}\text { Disagree } \\
\text { Neutral }\end{array}$ & 17 & 20.5 & 20.5 & 100.0 \\
& 83 & 100.0 & 100.0 & \\
Total & & & & \\
\hline
\end{tabular}

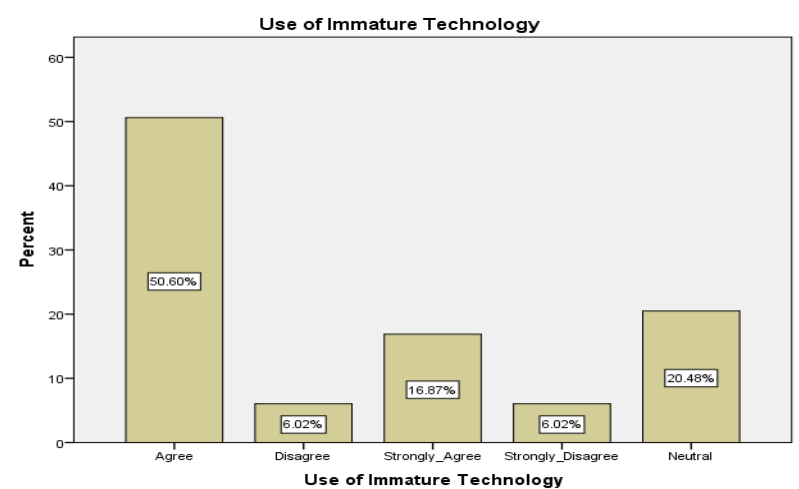

Fig.7. Software Technology Analyses

\section{Interpretation}

To analyze that at which extent software correlated component failure occur due to the use of immature technology, after doing a survey it conclude that almost $66 \%$ companies recognized that cause of correlated failure is use of wrong technology while developing a software.

\section{H. Software Developing Environment}

Table 8. Frequency of software Developing Environment

\begin{tabular}{|c|c|c|c|c|}
\hline & Frequency & Percent & $\begin{array}{c}\text { Valid } \\
\text { Percent }\end{array}$ & $\begin{array}{l}\text { Cumulative } \\
\text { Percent }\end{array}$ \\
\hline Agree & 35 & 42.2 & 42.2 & 42.2 \\
\hline Disagree & 5 & 6.0 & 6.0 & 48.2 \\
\hline $\begin{array}{l}\text { Strongly } \\
\text { Agree }\end{array}$ & 29 & 34.9 & 34.9 & 83.1 \\
\hline $\begin{array}{l}\text { Strongly } \\
\text { Disagree }\end{array}$ & 2 & 2.4 & 2.4 & 85.5 \\
\hline Neutral & 12 & 14.5 & 14.5 & 100.0 \\
\hline Total & 83 & 100.0 & 100.0 & \\
\hline
\end{tabular}




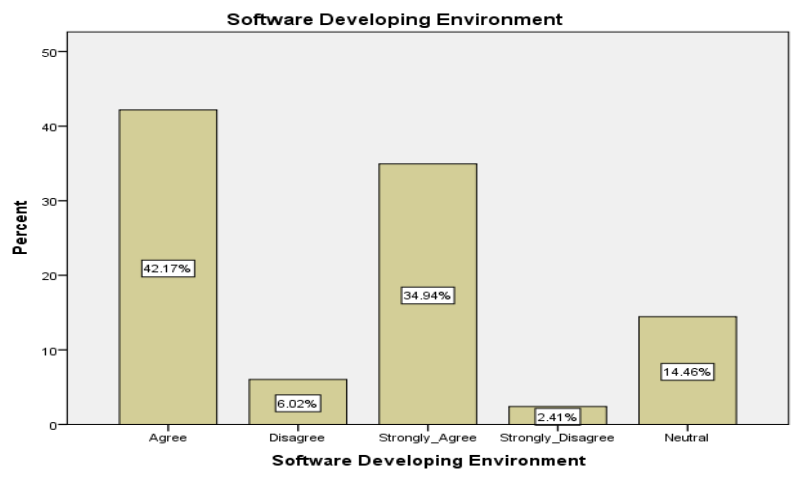

Fig.8. Software Developing Environment

\section{Interpretation}

To analyze that at which extent software correlated component failure occur due to the inappropriate software development environment, after doing a survey it conclude that almost $76 \%$ companies recognized that correlated failure occur due to the inappropriate software developing environment.

\section{Software Operating Environment Analysis}

Table 9. Frequency of Software Operating Environment

\begin{tabular}{|l|l|l|l|l|}
\hline & & & $\begin{array}{l}\text { Valid } \\
\text { Percent }\end{array}$ & $\begin{array}{l}\text { Cumulative } \\
\text { Percent }\end{array}$ \\
\hline Agree & 29 & 34.9 & 34.9 & 34.9 \\
Disagree & 16 & 19.3 & 19.3 & 54.2 \\
$\begin{array}{l}\text { Strongly } \\
\text { Agree }\end{array}$ & 11 & 13.3 & 13.3 & 67.5 \\
$\begin{array}{l}\text { Strongly } \\
\text { Disagree }\end{array}$ & 8 & 9.6 & 9.6 & 77.1 \\
Neutral & 19 & 22.9 & 22.9 & 100.0 \\
Total & 83 & 100.0 & 100.0 & \\
\hline
\end{tabular}

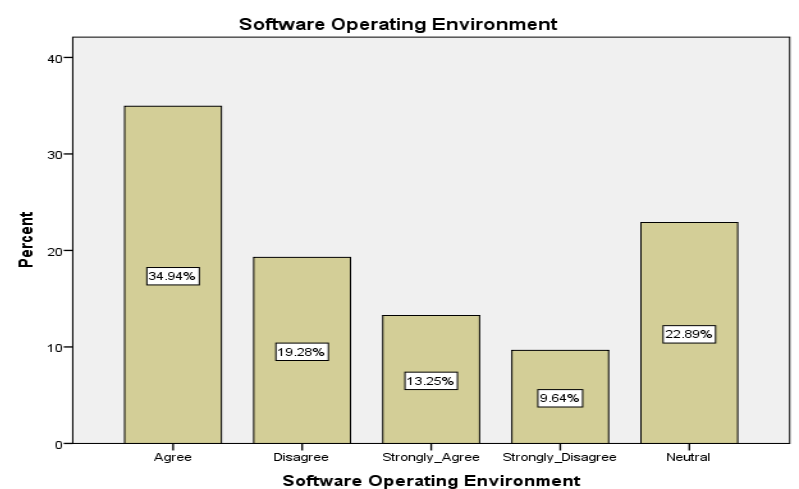

Fig.9. Software Operating Environment Analysis

\section{Interpretation}

To analyze that at which extent software correlated component failure occur due to the inappropriate software operating environment, after doing a survey it conclude that almost $47 \%$ companies recognized that correlated failure occur due to the inappropriate software operating environment.

\section{J. Software Design Analysis}

Table 10. Frequency of Software Design Analysis

\begin{tabular}{|l|r|r|r|r|}
\hline & Frequency & Percent & $\begin{array}{c}\text { Valid } \\
\text { Percent }\end{array}$ & $\begin{array}{c}\text { Cumulative } \\
\text { Percent }\end{array}$ \\
\hline Agree & 29 & 34.9 & 34.9 & 34.9 \\
Disagree & 5 & 6.0 & 6.0 & 41.0 \\
Strongly & 26 & 31.3 & 31.3 & 72.3 \\
Agree & & & & \\
Strongly & 3 & 3.6 & 3.6 & 75.9 \\
Disagree & 20 & 24.1 & 24.1 & 100.0 \\
Neutral & 83 & 100.0 & 100.0 & \\
Total & & & \\
\hline
\end{tabular}

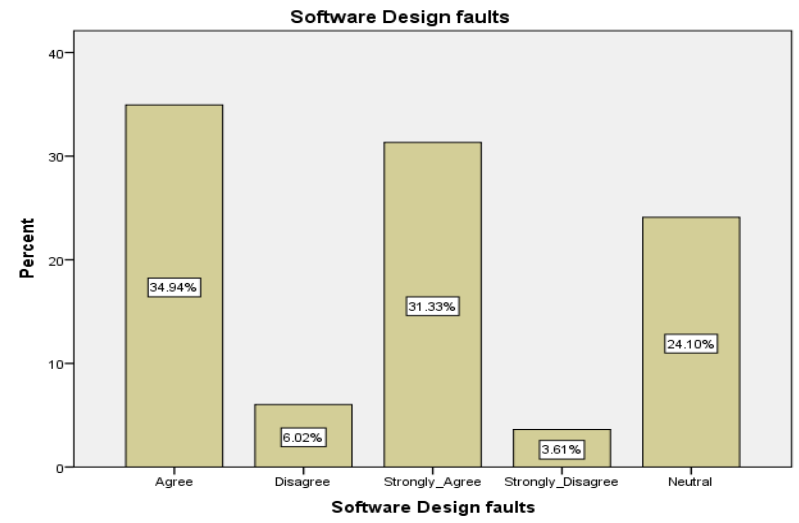

Fig.10. Software Design Analyses

\section{Interpretation}

To analyze that at which extent software correlated component failure occur due to the faults in software design phase, after doing a survey it conclude that almost $65 \%$ companies recognized that correlated failure occur due to the inaccurate design of the software.

\section{K. Software Fault Identification at Development Phase}

Table 11. Frequency of Software Fault Identification at Development Phase

\begin{tabular}{|l|r|r|r|r|}
\hline & Frequency & Percent & $\begin{array}{r}\text { Valid } \\
\text { Percent }\end{array}$ & $\begin{array}{c}\text { Cumulative } \\
\text { Percent }\end{array}$ \\
\hline Agree & 25 & 30.1 & 30.1 & 30.1 \\
Disagree & 9 & 10.8 & 10.8 & 41.0 \\
Strongly & 32 & 38.6 & 38.6 & 79.5 \\
Agree & & & & \\
Strongly & 3 & 3.6 & 3.6 & 83.1 \\
Disagree & 14 & 16.9 & 16.9 & 100.0 \\
Neutral & 83 & 100.0 & 100.0 & \\
Total & & & \\
\hline
\end{tabular}




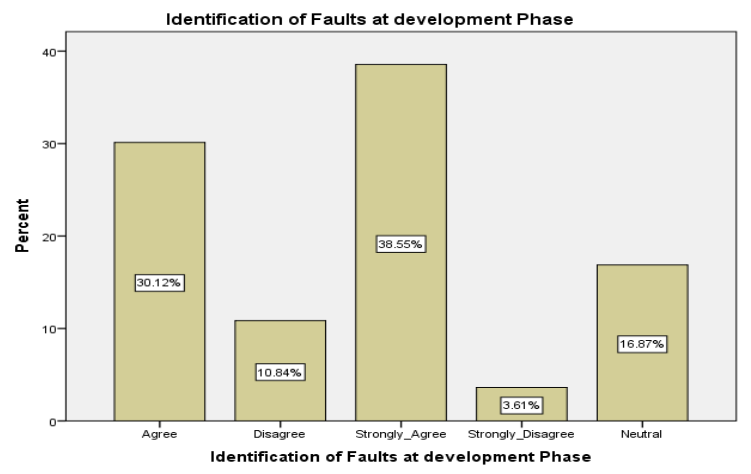

Fig.11. Software Fault Identification at Development Phase

\section{Interpretation}

To analyze that at which extent software correlated component failure occur due to the identification of faults at development phase, after doing a survey it conclude that almost $68 \%$ companies recognized that correlated failure occur due to the identification of faults at development phase.

\section{Software Fault Identification at Implementation} Phase

Table 12. Frequency of Software Fault Identification at Implementation Phase

\begin{tabular}{|c|c|c|c|c|}
\hline & Frequency & Percent & $\begin{array}{l}\text { Valid } \\
\text { Percent }\end{array}$ & $\begin{array}{l}\text { Cumulative } \\
\text { Percent }\end{array}$ \\
\hline Agree & 26 & 31.3 & 31.3 & 31.3 \\
\hline Disagree & 14 & 16.9 & 16.9 & 48.2 \\
\hline $\begin{array}{l}\text { Strongly } \\
\text { Agree }\end{array}$ & 20 & 24.1 & 24.1 & 72.3 \\
\hline $\begin{array}{l}\text { Strongly } \\
\text { Disagree }\end{array}$ & 3 & 3.6 & 3.6 & 75.9 \\
\hline Neutral & 20 & 24.1 & 24.1 & 100.0 \\
\hline Total & 83 & 100.0 & 100.0 & \\
\hline
\end{tabular}

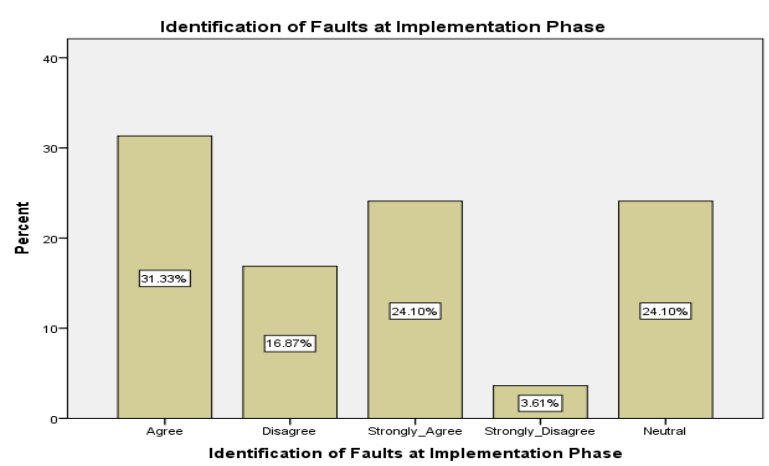

Fig.12. Software Fault Identification at Implementation Phase

\section{Interpretation}

To analyze that at which extent software correlated component failure occur due to the identification of faults at implementation phase, after doing a survey it conclude that almost $55 \%$ companies recognized that correlated failure occur due to the identification of faults at implementation phase.

\section{Software Testing Analysis}

Table 13. Frequency of Software Testing Analysis

\begin{tabular}{|l|r|r|r|r|}
\hline & Frequency & Percent & $\begin{array}{c}\text { Valid } \\
\text { Percent }\end{array}$ & $\begin{array}{c}\text { Cumulative } \\
\text { Percent }\end{array}$ \\
\hline Agree & 38 & 45.8 & 45.8 & 45.8 \\
Disagree & 5 & 6.0 & 6.0 & 51.8 \\
Strongly & 32 & 38.6 & 38.6 & 90.4 \\
Agree & & & & \\
Strongly & 3 & 3.6 & 3.6 & 94.0 \\
Disagree & 5 & 6.0 & 6.0 & 100.0 \\
Neutral & 83 & 100.0 & 100.0 & \\
Total & & &
\end{tabular}

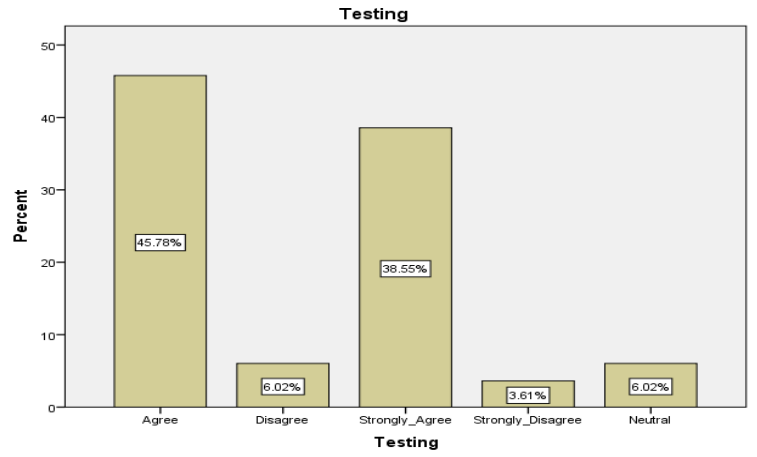

Fig.13. Software Testing Analysis

\section{Interpretation}

To analyze that at which extent software correlated component failure occur due to the faults in testing phase, after doing a survey it conclude that almost $83 \%$ companies recognized that correlated failure occur due to the error in testing phase.

\section{N. Security Policy Analysis}

Table 14. Frequency of Security Policy Analysis

\begin{tabular}{|l|r|r|r|r|}
\hline & Frequency & Percent & $\begin{array}{c}\text { Valid } \\
\text { Percent }\end{array}$ & $\begin{array}{c}\text { Cumulative } \\
\text { Percent }\end{array}$ \\
\hline Agree & 29 & 34.9 & 34.9 & 34.9 \\
Disagree & 4 & 4.8 & 4.8 & 39.8 \\
Strongly & 36 & 43.4 & 43.4 & 83.1 \\
Agree & & & & \\
Strongly & 2 & 2.4 & 2.4 & 85.5 \\
Disagree & 12 & 14.5 & 14.5 & 100.0 \\
Neutral & 83 & 100.0 & 100.0 & \\
Total & &
\end{tabular}




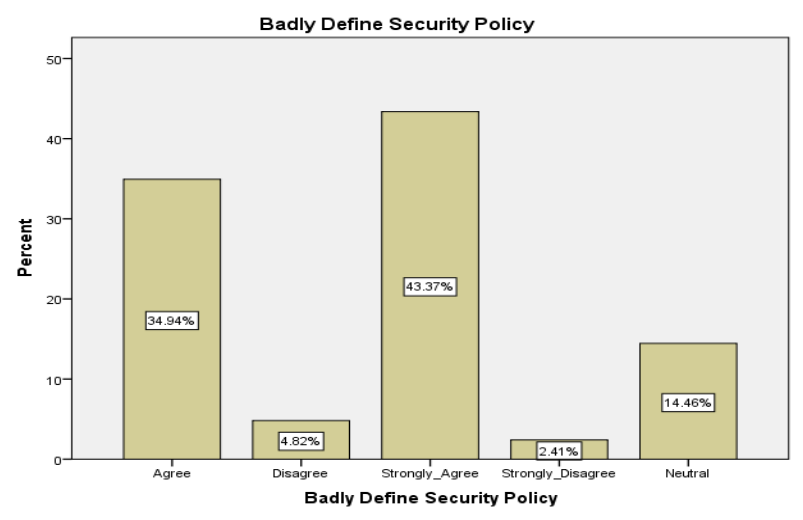

Fig.14. Security Policy Analyses

\section{Interpretation}

To analyze that at which extent software correlated component failure occur due to the badly define security policy of the software, after doing a survey it conclude that almost $77 \%$ companies recognized that correlated failure occur due to badly define software security policy.

\section{O. Untrained Software Developer}

Table 15. Frequency of Untrained Software Developer

\begin{tabular}{|c|c|c|c|c|}
\hline & Frequency & Percent & $\begin{array}{c}\text { Valid } \\
\text { Percent }\end{array}$ & $\begin{array}{c}\text { Cumulative } \\
\text { Percent }\end{array}$ \\
\hline Agree & 33 & 39.8 & 39.8 & 39.8 \\
\hline Disagree & 4 & 4.8 & 4.8 & 44.6 \\
\hline $\begin{array}{l}\text { Strongly } \\
\text { Agree }\end{array}$ & 16 & 19.3 & 19.3 & 63.9 \\
\hline $\begin{array}{l}\text { Strongly } \\
\text { Disagree }\end{array}$ & 3 & 3.6 & 3.6 & 67.5 \\
\hline Neutral & 27 & 32.5 & 32.5 & 100.0 \\
\hline Total & 83 & 100.0 & 100.0 & \\
\hline
\end{tabular}

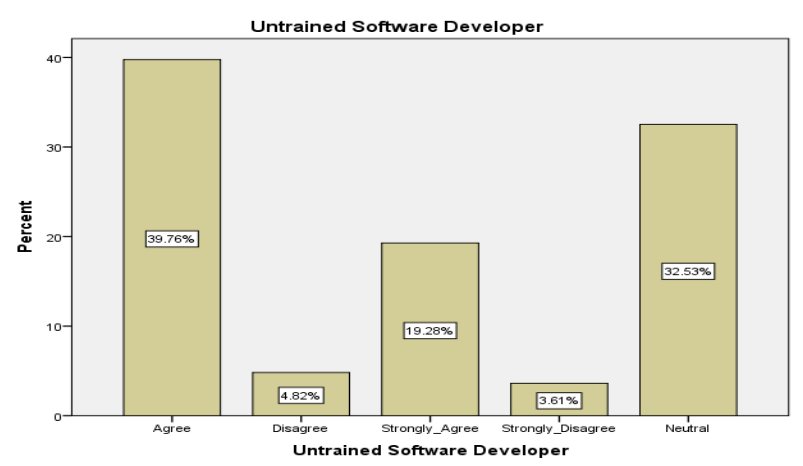

Fig.15. Untrained Software Developers Analysis

\section{Interpretation}

To analyze that at which extent software correlated component failure occur due to the untrained or uneducated software developer, after doing a survey it conclude that almost $58 \%$ companies recognized that correlated failure occur due to the untrained developer.

\section{CONCLUSION}

The objective of this research is identified the factors which are the cause of software failure in Pakistan industry, after doing a statistical analysis concluded that main reason of software correlated component failure is that error in software development and design phase, faults in defining software security policy, resource allocation process is not perform in better manner and the most important factor is testing which is not execute in efficient manner. It also analyze that in this world of complexity the need of reliable software is very high as well as estimate after doing the survey that correlated failure of the software is the main cause of software reliability decrement.

\section{ACKNOWLEDGMENT}

This research supported by the Department of Computer Science at Agriculture University Faisalabad.

\section{REFERENCES}

[1] Ammann, P. and J. Offutt. 2011. Introduction to Software Testing.Cambridge University Press,pp:1-30.

[2] Brosch, F., H. Koziolek, B. Buhnova and R. Reussner. 2012. Architecture-based Reliability Prediction with the Palladio Component Model.IEEE Transactions on Software Engineering, 38(6):1319-1339. DOI: 10.1109/TSE.2011.94

[3] Dai, Y., M. Xie and K. Poh. 2005. Modeling and Analysis of Correlated Software Failures of Multiple Types. IEEE Transactions on Reliability, 54(1): 100-106. DOI: 10.1109/TR.2004.841709.

[4] Febrero, F., M. Calero and M. A.Chang. 2016. A Mapping Study of Software Correlated Failure Modeling. Information and Software Technology, 30(1): 639-649.

[5] Fiondella, L. and L.Panlop. 2014. Reliability of Two Mode Systems Subject to Correlated Failures. IEEE Transactions on Reliability, pp:879-889.DOI: 10.1109/RAMS.2014.6798438.

[6] Fiondella, L., S. Rajasekaran and S. S. Gokhale. 2013. Efficient Software Reliability Analysis with correlated component failure. .IEEE Transactions on reliability, 62(1): 244-255. DOI: 10.1109/TR.2013.2241131.

[7] Garousi, V. and M. V. Mantyla. 2016. When and What to Automate in Software Testing? A Multi-vocal Literature Review. Information and Software Technology, 76: 1-38. DOI: http://dx.doi.org/10.1016/j.infsof.2016.04.015.

[8] Hamill, M. and K.Goseva-Popstojanova. 2009. Common Trends in Software Fault and Failure Data, 35(4): 484496. Doi: 10.1109/TSE.2009.3.

[9] Jafary, B. and L. Fiondella. 2016. A Universal Generating Function-based Multi-state System Performance Model Subject to Correlated Failure.Reliability Engineering \& System Safety, 152: 16-27. DOI: 10.1016/j.ress.2016.02.004.

[10] Jatain, A. and Y. Yukti. 2014. Metrics and models for Software Reliability: A systematic review. 2014 International Conference on Issues and Challenges in Intelligent Computing Techniques (ICICT), pp: 210-214. 
Doi: 10.1109/ICICICT.2014.6781281.

[11] Kothari, C. R. 2006. Research Methodology: Method and Techniques ( $2^{\text {nd }}$ edi.). Delhi: New Age International Publishers.

[12] Nagaraju, V., V. V. Basavaraj and L. Fiondella. 2016. Software Rejuvenation of a Fault-tolerant Server Subject to Correlated Failure.Proceedings Annual Reliability and Maintainability Symposium, pp: 110-115.

[13] Park, J., H. Kim, J. Shin and J. Baik. 2012. An Embedded Software Reliability Model with Consideration of Hardware Related Software Failures. IEEE Sixth International Conference on Software Security and Reliability, pp: 207-214. DOI: 10.1109/SERE.2012.10.

[14] Saito, Y. and T. Dohi. 2016. Predicting Software Reliability via Completely Monotone Nonparametric Estimator with Grouped data.Journal of Systems and Software, 117:296-306.DOI: 10.1016/j.jss.2016.03.047.

[15] Yang, J., Y. Liu, M. Xie and M. Zhao. 2016.Modeling and Analysis of Reliability of Multi-release Open Source Software Incorporating Both Fault Detection and Correction Processes.Journal of Systems and Software,115:102-110. DOI: 10.1016/j.jss.2016.01.025.

[16] Zhai, E., R. Chen, D. L. Wolinsky and B. Ford. 2014. Heading off Correlated Failures through Independenceas-a-Service. Proceedings of the 11th USENIX Conference on Operating Systems Design and
Implementation, pp: $317-334$.

Authors' Profiles

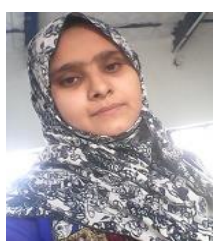

Darakshan Anjum Sialkot (Pakistan) 2611-1992. MS (Computer Science) in software Engineering from University of agriculture Faisalabad (Pakistan) in 2016. Major field of study is to estimate the correlated failure of software's.

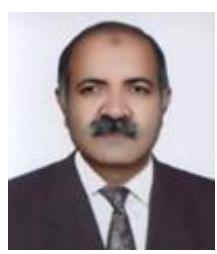

Tasleem Mustafa Faisalabad (Pakistan) MS (Computer Science) in Software Engineering Msc (Math) MIS (USA) major field of study is software reliability. Chairman/Assistant Professor, Department of Computer Science University of agriculture Faisalabad (Pakistan).

How to cite this paper: Darakshan Anjum, Tasleem Mustafa,"Reliability of Software Correlated Components Failure in Pakistan Industry", International Journal of Information Engineering and Electronic Business(IJIEEB), Vol.9, No.2, pp.27-35, 2017. DOI: 10.5815/ijieeb.2017.02.04 